\title{
The Changes in Online Buying Intention as a Determinant of Behavior During COVID-19 Pandemic in the Ready-Made Garments Industry in Egypt
}

\author{
Ashraf Elsafty ${ }^{1} \&$ Marwa Elshahed ${ }^{2}$ \\ ${ }^{1}$ Adjunct Assistant Professor, Eslsca University Egypt, Egypt \\ ${ }^{2}$ MBA Candidate, Eslsca University Egypt, Egypt \\ Correspondence: Ashraf Elsafty, Adjunct Assistant Professor, Eslsca University Egypt, Egypt. ORCID ID: \\ https://orcid.org/0000-0002-9377-7286 E-mail: ashraf@ashrafelsafty.com
}

Received: March 5, 2021

Accepted: March 31, 2021

Online Published: April 2, 2021

doi:10.5539/ijbm.v16n5p1

URL: https://doi.org/10.5539/ijbm.v16n5p1

\begin{abstract}
During 2020, in the time of the COVID-19 during and after lockdown. Governments are imposing lockdown and shutdown for all activities/services inside the country to reduce the spread of the previously mentioned pandemic including international flights. Major factories and manufacturers had stopped for months during the pandemic which led to having thousands of people with no salaries. Major companies resorted to work from home procedures whenever they can to keep the business going. This research will focus on the Online buying intention that eventually leads to buying behavior of Ready-made Garments in Egypt over the internet and social media, such as Facebook and Instagram to be specific. Readymade garment industry has started booming with the spread of e-commerce, especially with the influence of social media. Paper focuses on the area of greater Cairo and its resident customer segment of readymade garments, focusing on middle and upper social with minimum college education, who are also well-enabled with the needed resources to purchase products via the Internet.

The primary data was collected through Customer Interviews that were conducted through online questionnaires that resulted in the observation of COVID-19 as a catalyst for online shopping intention as a determinant of behavior since $32.5 \%$ of the respondents increased their buying frequency during the lockdown. The secondary data was collected through the review of previous researches, models and cases. Although the Online Buying Behavior is relatively a new phenomenon, the Buying behavior is quite rich with theories, a theoretical framework was proposed for the study of the online buying intention as a determinant of behavior that is based on Technology Acceptance Model (TAM) by Davis (1989) and 2 variables from Nayyar \& Gupta (2011) along with 2 moderating variables which are eWOM \& Psychological Factors and a mediating variable which is COVID-19.
\end{abstract}

Keywords: buying intention, consumer behavior, ready-made garments, internet shopping intention, COVID-19

\section{Introduction}

Ready-made Garments industry has evolved over the past couple of decades all over the world to become a multi-billion industry. The Ready-made Garments industry is one of the main pillars that supports the Egyptian economy according to El-Zarka (2010). The importance of this industry in Egypt arises from its 3 sectors, exports, imports and local sectors. Egypt is one of the top 20 countries in exporting and importing readymade garments (Teodoro \& Rodriguez, 2020). The exports sector is mainly dependent on Egypt's history of cotton along with the value of the Egyptian currency.

In order to ensure a comprehensive contextual analysis, researchers analyzed the research in hand with the perspective of the proposed contextual framework of Elsafty (2018) figure 1, that analyzes social and business study cases, as an anatomy model to closely study organizations and different contextual cases before attempting to solve any noticeable problems. On the way to contextual analysis of the research, Elsafty $(2018,2019,2020)$ provided a holistic framework to analyze the case using nine elements covering the whole ecosystem of educational organization(s) and all related stakeholders, including suppliers, distributors, customers, competitors, government agencies, and so on involved in the delivery of educational outcomes, and related service through both competition and cooperation. The nine elements framework has been used in several research papers (Elsafty, A., Elsayed, \& Shaaban, 2020; Elsafty A., \& AlNawaly, 2020; Elsafty A., \& Ragheb, 2020; Elsafty, A., \& Abadir \& 
Sharawy, 2020; Elsafty, A., Elbouseery, I., \& Shaarawy, A., 2020; Elsafty, A., \& Tahon, A., 2021; Elsafty, A., \& Elzeftawy, A., 2021).

According to Elsafty (2018) the Nine Elements Framework/Model can cover all sides around our problem we can understand our research problem through this model which explore the kind of research organization, management level, business functions, internal \& External environmental factors, geographical location and industry field we can explore all of this elements within time frame. Accordingly, the paper used the Nine Elements Framework/Model (ElSafty, 2018) to properly analyze and identify the problem of this paper in more details by applying and discussing each element of this model, which focuses on organizations and analyzing the external and internal environment, and through this we were able to identify the mutual impact between Turkish Islamic banks and the internal and external environment for them as follows:

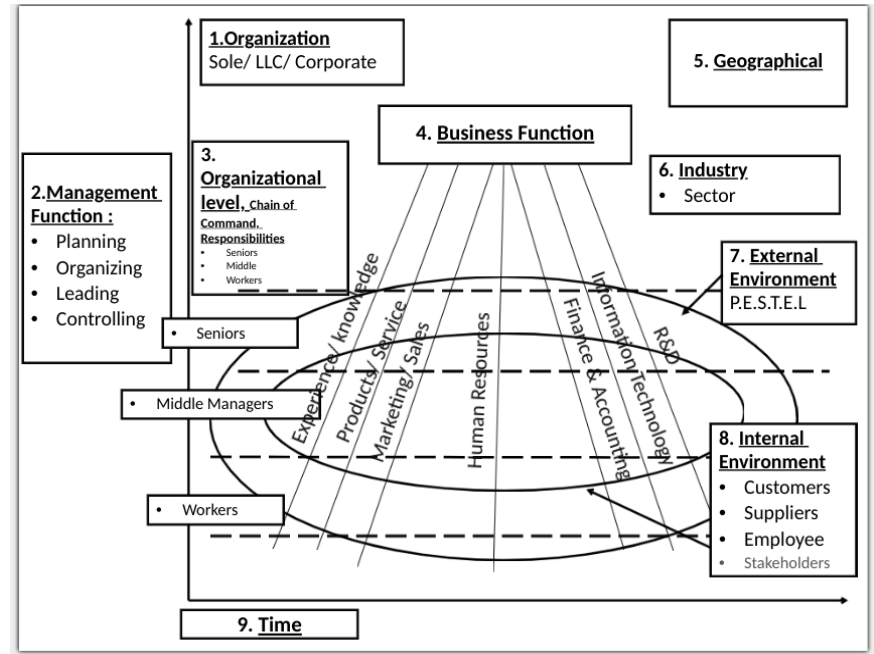

Figure 1. The nine elements framework/model of business analysis (Elsafty, 2018)

Starting with the Ready-made Garments industry that is to be discussed in this research. The labor costs are considered an advantage for production which reflects on the exports and the locally produced goods. As for the local market, it is divided into two parts, imports and locally produced. The imports section arise from the multinational clothing retail companies and online shopping platforms. While the local production, they range from major clothing retailers with their own factories to startups that are new in the market. Both sectors boosts the economy whether through online shops or physical outlets.

With a deeper look into this industry, the manufacturing process requires heavy machinery and labor involvement. While design and modeling are sometimes outsourced to external entities. There are also supporting industries for the readymade garment industry such as textile, weaving and machinery. These as well are mega industries not only in Egypt but all over the world. For the distribution, there are intermediaries in terms of warehousing activities for mass production and courier services for deliveries to outlets or end customers.

Using the PESTLE approach to study the external environment, the nation is quite stable since the president El-Sisi even with the existence of a slight opposition. The egyptian currency and exchange rate is currently stable which makes it suitable for production and export in all industries. Focusing on the readymade garments industry, it has a huge impact on the egyptian economy in terms of export or import as the industry is well saturated in the economy as the fashion and clothing trends are fastly adapted in the egyptain society regardless of status or gender or age. There are several plants and factories for readymade garments in the Greater Cairo area and Alexandria. However, There's a downside for these factories and plants that they increase the pollution levels which negatively affects the ecological system. Technology has become an important enabler for this industry starting from weaving to textile as supporting industries. Technological factors affect the manufacturing and production processes as well as the warehousing and distribution. There is also another impact of technology on this industry from another perspective. With the booming of the internet all over the world. The number of internet users increased by $22 \%$ between 2019 and 2020 to become 54.74 million users, therefore Internet penetration in Egypt is at 54\% in January 2020 with average daily time spent on using the internet is 7 hours and 21 minutes (Kemp, 2020). Electronic Commerce (E-Commerce) has emerged to be one of the most important channels of commerce. E-Commerce is 
simply the act of selling and buying anything over the internet without the need for a physical shop. According to the global digital insights, $81 \%$ of the internet users searched for a product or service to buy over the internet, while $70 \%$ of the internet users visited online retail stores on the web, and $51 \%$ of the internet users purchased a product online (Kemp, 2020). It is now over hundreds of billions of dollars in industry all over the world. There are major companies that control this market for example, Amazon, Alibaba, so on. In the Egyptain market, there's Souq, Jumia, etc. A new trend has started which is to own an online shop over social media accounts such as Facebook and Instagram forming these new startups in the industry. While the medium to large corporations resorted to use online platforms for their own brand name in which they can offer all e-commerce practices. These means of e-commerce were met by a growing acceptance and adaptation over the last couple of years. This has opened a major link between ready-made garments and e-commerce that has made it possible for the consumers to direct their buying behavior online.

From a marketing perspective, the buying intention as a determinant of behavior of consumers is an essential phenomena to be studied. There's a complementary phenomenon with the spread of E-commerce which is the online buying behavior. It's a new behavior that has started by the booming of e-Commerce which measures the appeal and preference of consumers to move towards shopping over the internet instead of physical outlets. This behavior is growing in all sectors and industries. But this research will focus on online buying intention as a determinant of behavior. Also, with the influence of social media, consumers are more motivated to search for the trendiest outfits to match celebrities and social media influencers. The number of social media users increased by 7.3\% between April 2019 and January 2020 to become 42 million users, therefore social media penetration in Egypt is at $41 \%$ in January 2020 with average daily time spent on using social media is 2 hours and 57 minutes (Kemp, 2020). This has led to the courage of trying outfits online just to get the trendy look. Also, with a convenient return policy, consumers are able to try outfits at home and return the unwanted items. Customers of all segments consider these products as a necessity. However, each segment is interested in a certain sector or area of products. For Fashion, it's considered a top level of the ready-made garments industry according to Mishra \& Singh (2020). The segmentation is focused on middle and upper class customers to be able to have the luxury of affording following clothes trends and fashion. As a result, the Readymade garment industry started booming the last couple of years over the internet. The online buying intention as a determinant of behavior, in general, increased for any product or service. In Egypt, the online buying intention as a determinant of behavior for readymade garments is exponentially increasing. Overall, the concept is well accepted in the egyptain market especially in the middle and upper class of age over 18 years old which the targeted segment of this research.

Also, there's another phenomena that started affecting the online buying intention as a determinant of behavior which is the fear of missing out on an opportunity, an opportunity to buy a last item, or sale item or even buy an item that everyone is wearing all over social media even if it doesn't match or suit their style. This phenomena is well used and built upon in marketing for all industries especially in the fashion sector.

Meanwhile on the 11th March 2020, the World Health Organization (WHO) made the assessment that CoronaVirus Disease (COVID-19) is treated as a pandemic disease (Archived: WHO Timeline - COVID-19, n.d.). A viral disease that originally started in Wuhan, China that spreads between humans and animals via droplets and/or contact with the infected. This disease is from the Corona virus family, such as Middle East Respiratory Syndrome (MERS) and Severe Acute Respiratory Syndrome (SARS). Its symptoms range from common cold, flu, fever to severe pneumonia. There's no definite cure yet for this disease. However, WHO recommends washing hands with soaps regularly and using alcohol for disinfection to decrease the infection.

Governments accordingly started lockdown and social distancing procedures in order to maintain the impact of this virus. Egypt is one the countries that was invaded by the virus. Curfew and lockdown was applied as well as enforced by the government. However, there are still new cases and social distancing procedures are put in place in order to limit the spreading of the virus. As a result, the consumers buying resorted to the internet to fulfill their needs. E-Commerce was nurtured with the COVID-19 in different ways. The online channels solved all obstacles created by the lockdown and social distancing.

\subsection{Stakeholder Analysis}

The online purchase transaction is done by a seller to a customer and delivered to the customer via a courier service provider. Therefore, stakeholders can be classified in sellers, customers and courier service providers that mediate between the seller and customers in the process of the online purchase.

\subsubsection{Sellers}

The clothes retailers vary in their organization structures from multinational corporations to start-ups in which they use imported items or manufacture in local factories. Basically, startups begin with new entrepreneurs with little to 
no background in management. their chain of command is small to non-existent, most of them are managed by their owners and most functions are outsourced on the go. As for the business functions, marketing and sales are of focus so as to help the business running. These shops are virtual shops typical over social networks such as Facebook and Instagram. The garments are marketed online via paid campaigns over the internet in terms of posts of media content. Some of these shops have websites as well, in which you search, select and order from. The purchase process is done either via texting the merchant or online by adding to cart on the website. then the order will be delivered to the customer via an external courier company. The payment is handled either online in case of website or cash on delivery. The return policy is not very convenient is you need to pay the courier to return the wanted items. The manufacturing process is done through an external factory according to a specific design.

The online shops structure functions, marketing is done over social media, delivery and manufacturing are often outsourced to external entities. While the owner is basically focused on the design and modelling and financial management.

As for the major local companies, such as Mobaco cotton, the organization structure and chain of command are fully structured in order to operate. As for the business functions, they are in need of more advanced functions in order to manage such organization. They use their own factories and design in house. As for the multinational corporations such as H\&M, Zara and Mango. All manufacturing, production and designing functions are executed outside Egypt except for Marketing, Sales and Finances. They also have more advanced features to offer to the market in order to have the competition that they have now. They have their websites that offer the online experience in which you can select, save your favorites, ship to store, pay online, have it delivered to your doorstep. They also can offer online chat and customer service to help with their experience.

As example companies for Clothes shops, Local brands e.g. Al-Tawheed wel nour, International brands e.g Mango, Zara, Online shops Souq \& Jumia, stores over Facebook and Instagram. And buying from abroad upon request e.g. Yashry.

\subsubsection{Courier Service Providers}

Courier Services has boomed recently in Egypt to fulfil the increased need for delivery and pickup functions between the sellers and consumers via virtual shops. Also, with the COVID-19 Pandemic, these services also increased to enable the social distancing procedures.

In Egypt, courier companies are divided into 2 categories, international and local companies. The international companies such as FedEx or DHL are market leaders and offer advanced services in terms of having an App, tracking for orders and customer service functions such as hotlines. While Local companies provide basic services with a pricing edge in order to compete, basically they get the job done which is required with the online shopping retails.

\subsubsection{Customers}

Since the research is studying the online buying intention as a determinant of behavior, customers as stakeholders are of significant value to be analyzed. So In order to view the customers perspective on the problem, an interview with some customers was conducted. The interview was conducted through an online interview on Google Forms through social media using open-ended questions to reduce the influence on the respondents.

\section{Literature Review}

During the year 2020, the COVID-19 pandemic has impacted several industries all over the world. According to Mishra \& Singh (2020), there have been many losses in this sector as the challenges in the Ready-made Garments Industry increases during the COVID-19 pandemic as in terms of bulk production and labor management. However, the impact is similar to any other sector (Mishra \& Singh, 2020). The study from a public health perspective by Hasab, El-Ghitany, \& Ahmed (2020) shows that "Egypt COVID-19 epidemic situation is not frightening. Even though, strengthening all the mitigation efforts to keep the exposure probability, as well as the transmission rate as low as possible is mandatory for containment of the epidemic." (Hasab et al., 2020) which ensures that the economy and purchase power is not severely impacted by the pandemic. As long as there's purchase power, manufacturing and production will be motivated. Therefore, we can study the required phenomena. While Abdelhafz, Mohammed, Ibrahim, Ziady, Alorabi, Ayyad \& Sultan (2020) researched the attitude towards the virus in their study. It was concluded that "In general, Egyptians participating in our survey had good knowledge about COVID-19, and a positive attitude towards using protective measures, which is important to limit the spread of the disease" (Abdelhafz et al., 2020) which is a good indicator for using protective majors during interactions and also implies online shopping preference to ensure social distancing is applied.

This research is focused on studying these impacts as a form of opportunities or challenges for the RMG sector, 
e-commerce sector to be specific. According to Neger \& Uddin (2020), there are different classification for E-commerce. "E-commerce transactions may be made in four different ways, such as Business to Business (B2B), Business to Customer (B2C), Customer to Customer (C2C), and Customer to Business (C2B) (Topper)" (Neger \& Uddin, 2020). Therefore, this research will focus the study on direct to customer relationships such as Business to Customer (B2C) and Customer to Customer (C2C) relationships.

\subsection{Prior Theories on Behavior}

This is the first model to be examined in this research in Figure 2, the Theory of Reasoned Action (TRA) by Fishbein \& Ajzen (1975). It's a general theory for studying any behavior from which other models were developed (Fayad \& Paper, 2015). It's one of the famous theories in social psychology to help understand behavior and its motives. According to Fishbein and Ajzen (1975), the intention measures the effort to be done for a certain behavior. Therefore, the behavior is linked to the intention towards set behavior and this intention is powered by 2 factors, attitudes and subjective norms (Balau, 2018).

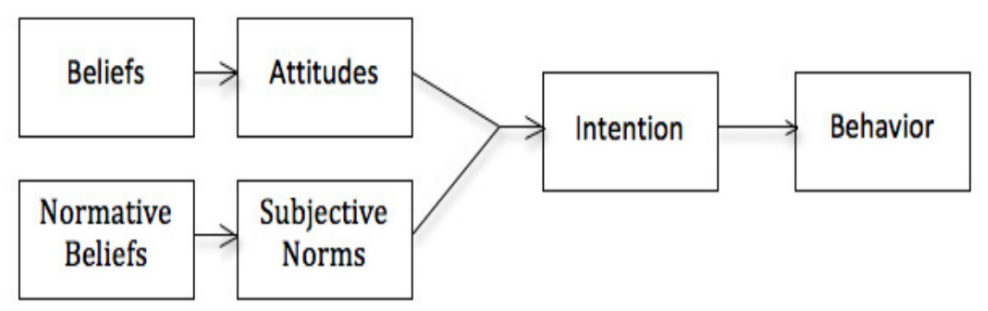

Figure 2. Theory of reasoned action (TRA) by Fishbein \& Ajzen (1975)

The second model is Technology Acceptance Model (TAM) by Davis (1989) in figure 3. It was based on the TRA by Fishbein \& Ajzen (1975) TAM is also used to predict intention which leads to behavior, with the introduction of 2 main variables, Perceived Ease of Use (PEOU) \& Perceived Usefulness (PU) and they reflect consumers' ability to use and how can their experience be enhanced (Ahmad et al., 2014).

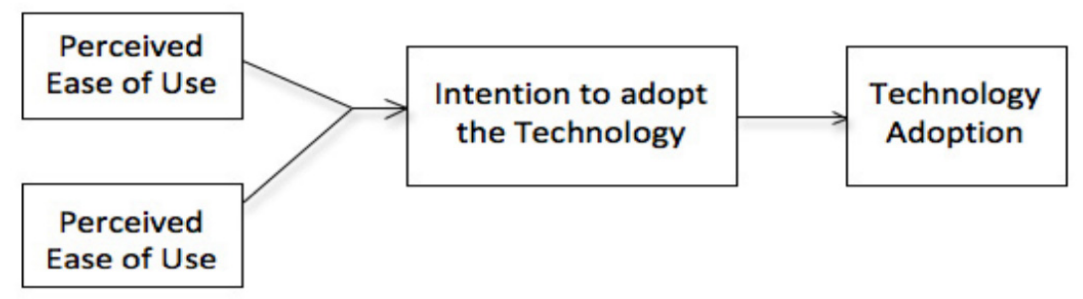

Figure 3. Technology acceptance model (TAM) by Davis (1989)

The third model is Theory of planned behavior (TPB) by Ajzen (1991) in figure 4. According to Fishbein and Ajzen (1975) Theory of planned behavior (TPB) studies the behavioral intention which can predict the behavior, there are 3 variables affecting the intention which are the attitude as in towards the e-commerce, subjective norm as in the circle of influence and perceived behavioral control as in the perception of ease or difficulty over a certain behavior (Pavlou \& Fygenson, 2006). 


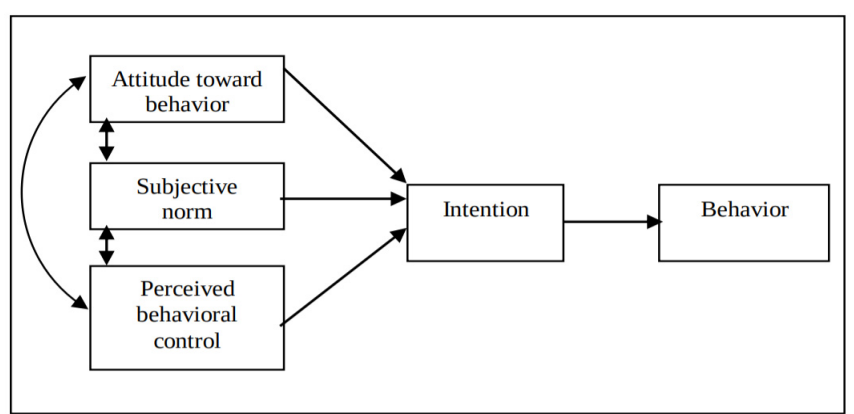

Figure 4. Theory of planned behavior (TPB) by Ajzen (1991)

The fourth model is Expectation Confirmation Theory (ECT) by (Oliver, 1980, 1993, Anderson \& Sullivan 1993) in figure 5. ECT focuses on expectation and post-purchase experience and its impact on the repurchase intention and therefore behavior, along with the Post-Acceptance Model (PAM) which measures the continuity of intention in the post purchase stage (Kim, 2012). ECT builds on customer satisfaction from which it can to repurchase behavior (Ahmad et al., 2014).

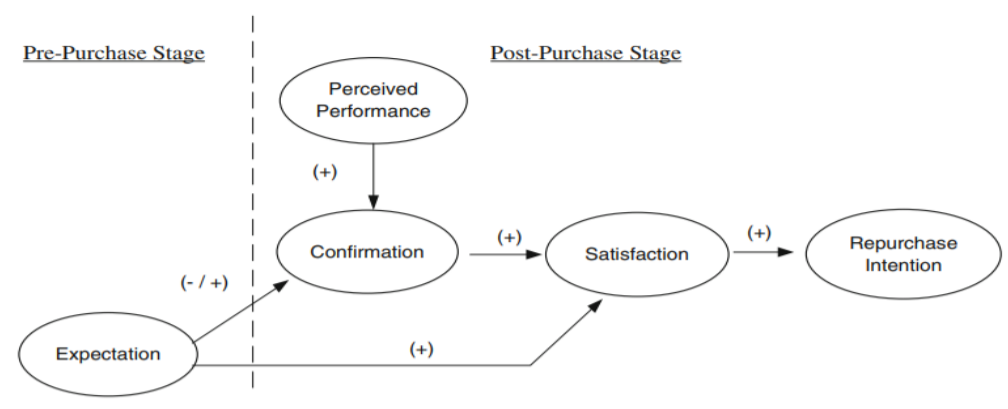

Expectation-Confirmation Theory (ECT): (Oliver, 1980, 1993, Anderson \& Sullivan 1993)

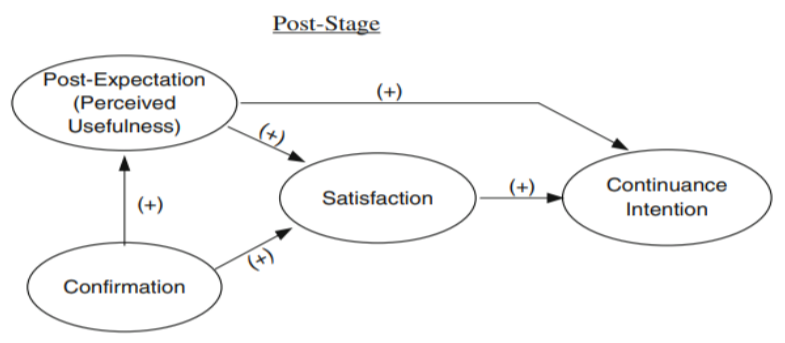

Post-Acceptance Model (PAM): (Bhattacherjee, 2001)

Figure 5. Expectation confirmation theory (ECT) by (Oliver, 1980, 1993, Anderson \& Sullivan 1993) \& Post-Acceptance Model (PAM) by Bhattacherjee (2001)

The fifth model is Innovation Diffusion Theory by Rogers (1995) in figure 6, these stages created by Rogers (1995). According to Şen (2019), online shopping is considered a new concept which means it went through innovation stages as innovation involves any new experiences for consumers. 


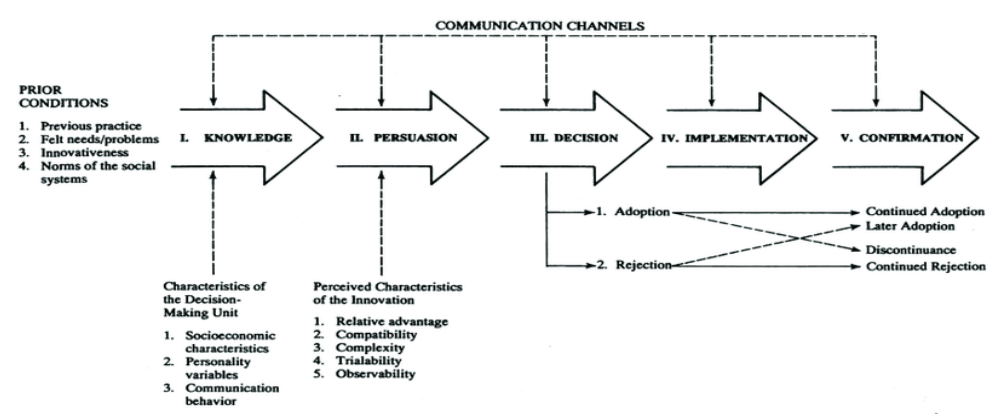

Figure 6. Diffusion of innovation by Rogers (1995)

The sixth model in figure 7, Şen (2019) created a model that included all previous theories to measure the online buying behavior plus she added consumer habits and trust as independent variables. for consumer habits, Habits are not the same as behavior, the repeat of the behaviors can create habits as habits are defined as automatic behaviors triggered by cues (Chiu et al., 2010). "Online shopping habits are defined as the extent to which buyers tend to shop online automatically because of learning” (Chiu et al., 2010). This means habits don't only induce behavior but increase repurchase intention. As for Trust, it means having a positive attitude towards behavior (Chiu et al., 2010). Therefore, habits and trust can influence behavior directly with the intention. The purchase behavior is often supported by a trust in the product or service (Kumar \& Dange, 2012).

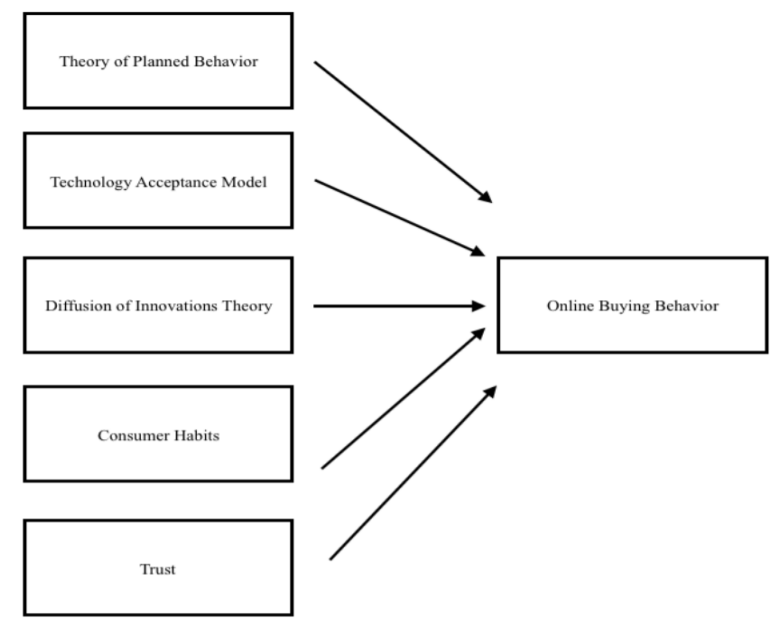

Figure 7. Comprehensive model by Şen (2019)

The seventh model Model of Intention, Adoption, and Continuance (MIAC) in figure 8. It links the three stages, intention, adoption and continuance, the consumer online purchase intention is followed by consumer online purchase which is the behavior then consumer online repurchase (Kumar \& Dange, 2012). This research is focused on the intention as a determinant of behavior so the continuance i.e. repurchase will be excluded from this study, and the intention will be the main focus of the following models.

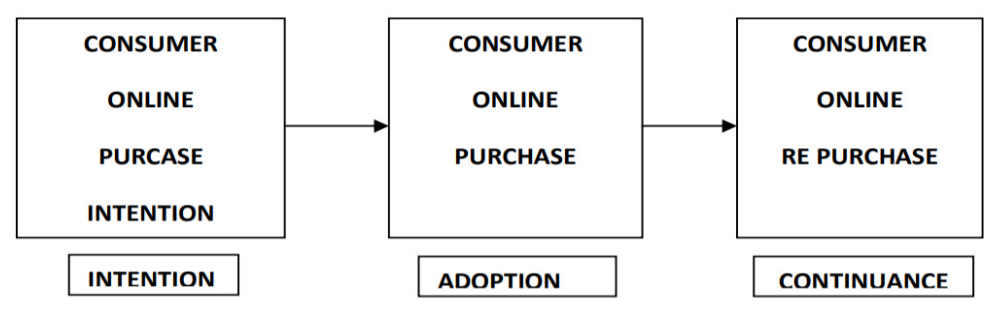

Figure 8. Model of Intention, Adoption, and Continuance (MIAC) 


\subsection{Previous Research and Cases}

In figure 9, Neger \& Uddin (2020) defined Internet Shopping Behavior as using e-commerce in the process of the purchasing. Below are the variables considered in the previously mentioned research: Product factor, Price Factor, Time Saving Factor, Payment Factor, Security Factor, Administrative Factor, Psychological Factor (Neger \& Uddin, 2020). For the Product Factor, "The product can be anything like good, service, people, place, idea, information and organization that seek attention and try to satisfy the needs, wants, or desires of the consumers" (Neger \& Uddin, 2020). In this research, the product is not a variable, rather a fixed attribute which is online purchased ready-made garments. The model used by Neger \& Uddin (2020) is applicable to any product while this research is studying ready-made garments so this variable will be fixed as online purchased ready-made garments. Price can be defined as monetary costs that need to be paid in exchange for a product or service or any other value that has to be paid by consumers to select, buy, or use products or services (Kotler \& Armstrong, 2012). Since this research is studying the online behavior to purchase, it's assumed that the buying power is existent as mentioned in the internal environment analysis in terms of the social class selected in this study. The sensitivity of the price is reflected in another attribute (FOMO) in terms of sales and promotions. As for the Time Saving Factor, "Time saving demonstrates consumers require less time to shop in the retail stores, fast transaction speed, without standing in a long line at these stores" (Neger \& Uddin, 2020). According to the definition of diversity in this research conceptual model, consumers are able to scan hundreds of products in a timely manner while the same process could take days or even not possible in the old fashion way using retail stores. As for the Payment Factor, E-payment system covers any payment system that allows users to transact digitally over the internet (Humphrey, Pulley, \& Vesala, 1996). According to the definition of the ease of use, the payment factor is one the attributes that eases the use of the online transaction especially in case of e-payment. As for the Security Factor, "During internet shopping, consumers and trade organizations have to process vast data and information related to the consumers and their personal information" (Neger \& Uddin, 2020). For Security, according to the Conceptual model, security is considered a risk as shoppers are sharing lots of personal information during the process of shopping online. However, there are many rules and regulations to be followed by companies to help secure and protect consumers' data. As for the Administrative Factor, The role of the government with the introduction of e-commerce in developing countries (Neger \& Uddin, 2020). Although Egypt is a developing country, it's considered a consuming country. E-commerce is considered accepted and saturated in the community according to the stakeholders analysis. As for the Psychological Factor, "The psychological factor consists of four key elements: motivation, perception, learning, and attitudes or beliefs" (Neger \& Uddin, 2020). According to the conceptual model, the fear of missing out is psychological phenomena that affects the shoppers behavior.

The conclusion of the study is that "all factors except price factor and security factor had a momentous and positive association with consumers' internet shopping behavior during the coronavirus disease (COVID-19) pandemic in Bangladesh" Neger \& Uddin (2020).

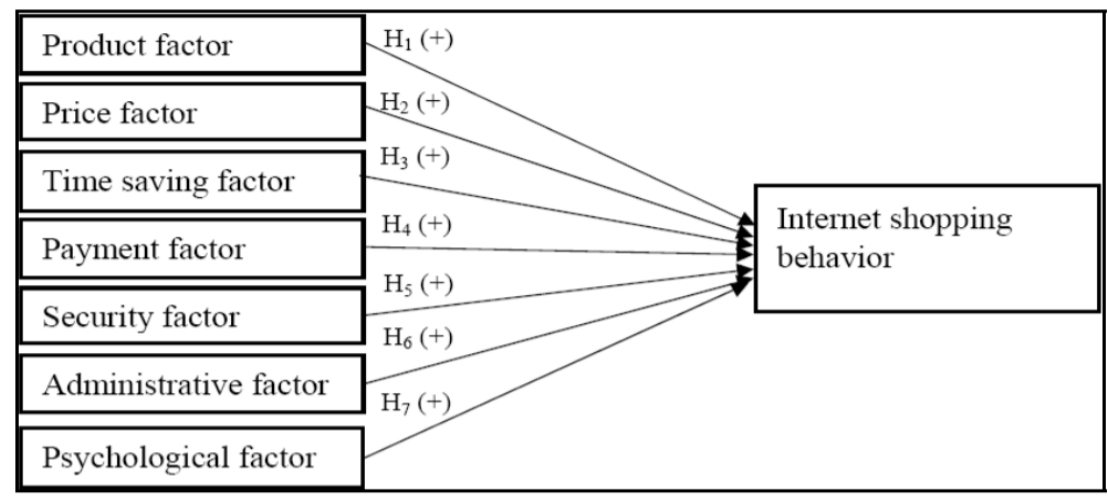

Figure 9. Factors affecting consumers' internet shopping behavior during the covid-19 pandemic: evidence from Bangladesh research model by Neger \& Uddin (2020)

In figure 10, El Ansary \& Roushdy (2013) studied the Factors that affect Egyptian consumers' intentions for accepting internet shopping as predicate to actual behavior, as the dependent variable, their model included the following variables, the independent variables considered in this research are trust in website, e-service quality, consumers attitude toward online shopping with the addition of demographic characteristics as a moderating variable. (El Ansary \& Roushdy, 2013). As for the e-service quality, it has different parameters that are used for 
evaluation. From the factors that affect the E-service quality is the transactions, communication with the seller and website use (El-Ansary \& Roushdy, 2013) while According to the ease of use factor, convenience reflects the e-service quality in the conceptual model. As for the trust factor; "All the studies suggest that trust is central to interpersonal and commerce relationships and is also widely applied in organizations" (El-Ansary \& Roushdy, 2013). According to the Conceptual model, security is considered a risk as shoppers are sharing lots of personal information during the process of shopping online. However, there are many rules and regulations to be followed by companies to help secure and protect consumers' data. As for the Attitude toward buying online; "Based on the literature, it is reasonable to expect that the more positive attitude toward the online store, the greater amount of search intention for product information via the online store" (El-Ansary \& Roushdy, 2013). As for the Demographic characteristics; "are measured by gender, age, experience with the internet, and educational level" (El-Ansary \& Roushdy, 2013). The demographic factors were first introduced in the internal environment analysis and stakeholder analysis so as to select the targeted segment of the study.

The conclusion of study confirmed all other factors and rejected e-Service quality as the Egyptain society was more influenced by the risks rather the quality (El-Ansary \& Roushdy, 2013). This will be adapted directly as the research was done in Egypt and in similar demographic settings.

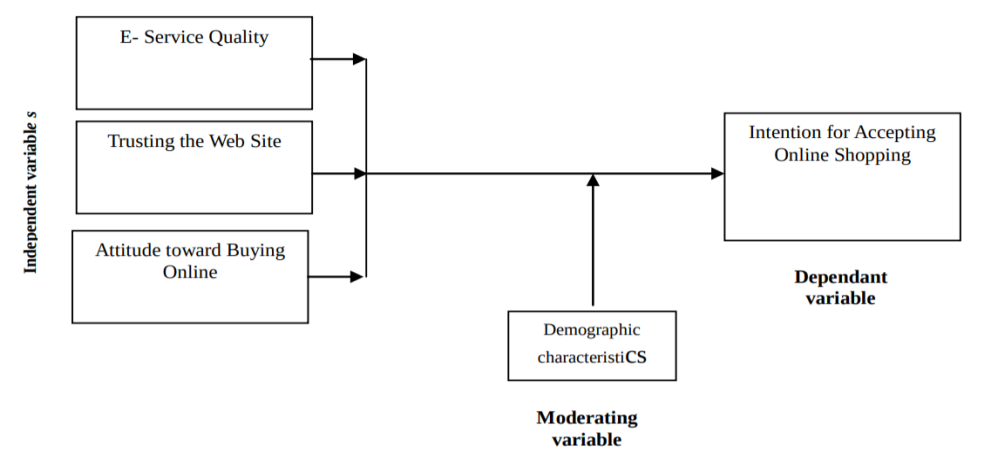

Figure 10. Factors affecting Egyptian consumers' intentions for accepting online shopping research model by El Ansary \& Roushdy (2013)

In figure 11, Aref and Okasha (2020) studied the online shopping behavior among college-educated community in Egypt to find that "perceived enjoyment, perceived ease of use, social norm and perceived risk have significant influences on the respondents to shop online; while the site language effect was insignificant" (Aref \& Okasha, 2020). Their model was based on the TAM with an adaptation of Perceived Enjoyment as introduced by (Davis, 1993), the perceived enjoyment induces the amount of time spent surfing and shopping on a certain website (Aref \& Okasha, 2020). As for the social norm, it can be reflected as one of the parameters of psychological factors, while Internet experience can be included in the demographic characteristics, as for the site language is rejected since it has been proved insignificant. 


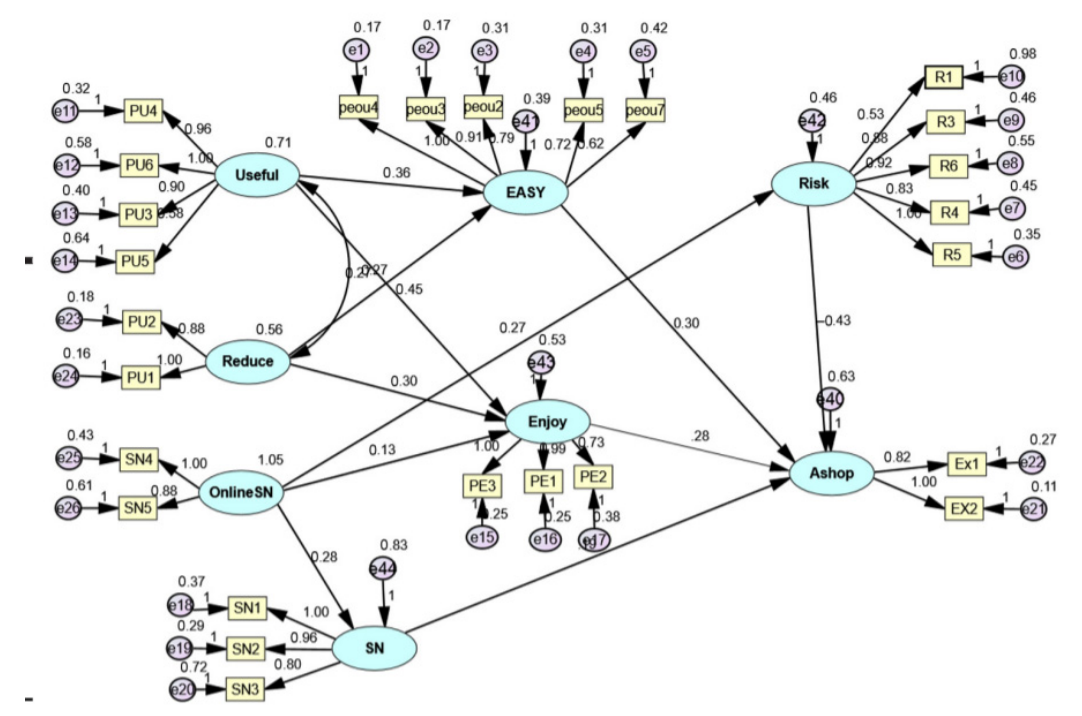

Figure 11. Evaluating the online shopping behavior among Egyptian college-educated community Research Model by Aref \& Okasha (2020)

In figure 12, Vazquez \& Xu (2008) investigated the linkages between the online purchase behavior variables, the variables were classified in time order as antecedent variables; intervening variables (online shopping motivations, attitude towards online shopping and online information search); and outcome variables which is the online purchase intention. This classification shows the process that the consumer goes through starting from his internal feelings to the actual action. Their conclusion is that "measuring the effect of online shopping motivations is highly significant on consumers' online information search behaviour" (Vazquez \& Xu, 2008). Their finding is relevant to this research as the knowledge about the online shopping is very basic and essential to build upon and study the online buying behavior. The consumers must be aware of the tools of the e-commerce to be able to dive in the internet shopping. Also, "the relationship between online shopping motivations and information search and evaluation was the strongest relationship in the framework" (Vazquez \& Xu, 2008). This is reflected in this research's conceptual model in the diversity variable as the ability to search, choose and evaluate alternatives is a key component of online shopping.

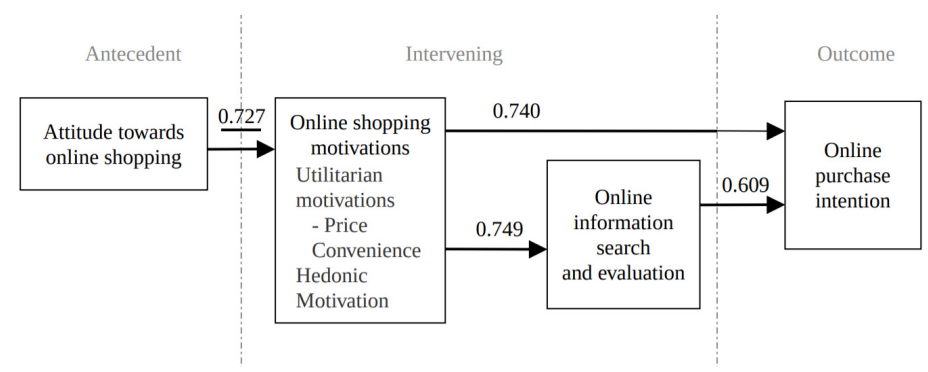

Figure 12. Online shopping framework by Vazquez \& Xu (2008)

In figure 13, Nayyar \& Gupta (2011) studied the following variables, Demography, perceived usefulness, perceived ease of use, perceived risk as determinants of internet buying behavior. Given the demographics, it was found that the gender differences have an effect; "The findings of this study have revealed a higher number of male internet shoppers than females" (Nayyar \& Gupta, 2011). In addition to the introduction of a new parameter to classify and segment the consumers as PC literate and illiterate, therefore, the PC illiterate are out of scope of this study. The PC literate population with higher exposure and awareness of the internet were considered in this study with significance with the education level (Nayyar \& Gupta, 2011). PC literate consumers can be considered of a minimum education level, however as the education level increases, there's no more significant effect. Both factors classify the target consumer segment of this study. Also, higher income and higher positions were associated with more awareness of technology and more purchasing power (Nayyar \& Gupta, 2011). The level of 
income implies having the privilege of shopping while education level and PC literate factors qualifies the ability to use online shops. As for the "Perceived ease of use on the other hand, indicates how the users perceive the ease of using the technology" (Nayyar \& Gupta, 2011). This has been reflected in the Ease of use factor in the conceptual model in terms of convenience, availability, accessibility and payment method. "Perceived risk is defined as a functional or psychosocial risk a consumer feels he or she is taking when purchasing a product" (Nayyar \& Gupta, 2011). This can be reflected in the Security factor in this research conceptual model in terms of purchase and return policy, fraud and secure payments. Perceived usefulness is measured through the improvement incurred due to the use of technology in terms of performance or productivity (Nayyar \& Gupta, 2011). This can be reflected in the Diversity factor in the conceptual model in terms of variety of alternatives, reviews and comparisons.

This model has adapted the TAM in a simple yet fruitful approach, it has also shed some light on the different parameters of the demographic characteristics to evaluate individual differences.

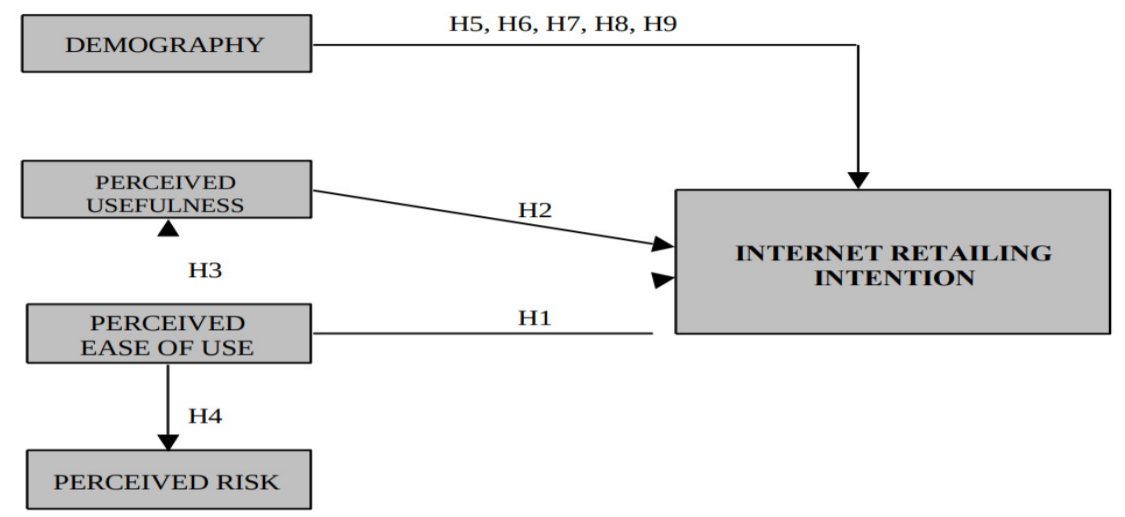

Figure 13. Determinants of internet buying behavior in India research model by Nayyar \& Gupta (2011)

Sien and Falahat (2015) investigated Consumers' Purchase Intention towards Online Group Buying in which they defined "Online group-buying (OGB) has emerged with the advent of e-commerce and social networking" (Sien \& Falahat, 2015). The online group-buying was reflected in the problem as the online shops over social media which has recently been spreading. In figure 14, the variables included in the study were: perceived usefulness, perceived ease of use, price, electronic word of mouth, trust and perceived risk (Sien \& Falahat, 2015). Focusing into the social media influence which can be modified into electronic word of mouth as it was observed in the problem. The electronic word of mouth (e-WOM) is derived from the traditional word of mouth communication that is commonly spread through the circle of influence. However, with the acceptance of digital information and of e-commerce, the e-WOM became even more influential as the product reviews and quality and sales are shared over social media platforms (Sien \& Falahat, 2015). Although the research is conceptual and has not been put to test, it can be concluded that the electron word of mouth effect was observed and linked to online buying intention in different environments.

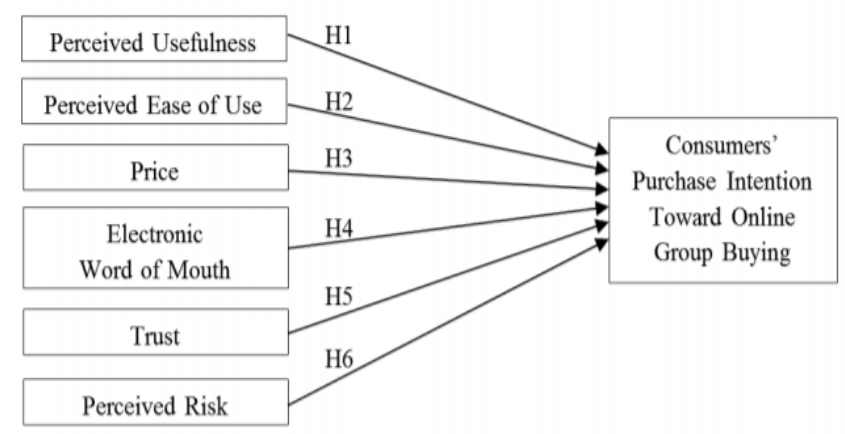

Figure 14. Conceptualising consumers' purchase intention towards online group buying conceptual model by Sien \& Falahat (2015) 
In figure 15, Rahman, Khan, Abdul Hamid, Latiff, \& Mahmood (2018) studied the relation between the e-WOM and the Online Purchase Intention in which they classified the e-WOM into two categories, market level and individual. Since this research is studying online buying intention, the focus will be on the individual analysis for consumer behavior. They also studied the evolution of the e-WOM from text-based to picture-based and video-based reviews as its influence grew to affect millions of consumers and technology advancement enabled it (Rahman et al., 2018). As the e-WOM evolves as it becomes a more reliable and mature source of information that consumers can use to decrease their perceived risks on their online buying intention. The study also included the relation between e-WOM \& Brand Image and Brand Image \& Online Purchase Intention, the findings of the study is that e-WOM and brand image is a significant driver of online purchase intention, also e-WOM is a significant driver of brand image (Rahman et al., 2018). According to which the e-WOM has direct and indirect effect on the online buying intention.

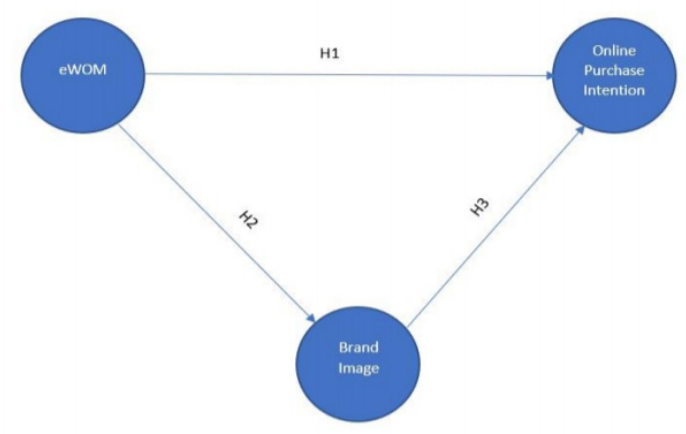

Figure 15. Impact of electronic word of mouth (e-WOM) on brand image and online purchase intention by Rahman, Khan, Abdul Hamid, Latiff, \& Mahmood (2018)

In Figure 16, according Xiaorong, Bin, Qinghong, Liuli, \& Yu (2011); their model is based on consumers' cognitive, affective and behavior hierarchy which is the theory of reaction, similarly the eWOM information, consumer trust, purchase intention with the addition of product type as moderator. This model explains the dimensions of the e-WOM in any consumer environment which adds confidence that this variable affects the online buying intention directly or indirectly. The study concluded that eWOM information quantity and eWOM timeliness is significantly positively related to consumer trust and consumer trust is significantly positively related to purchase intention (Xiaorong, Bin, Qinghong, Liuli, \& Yu,2011). The conclusion helps provide a recommendation to be used that eases the consumer evaluation of the received information over the internet.

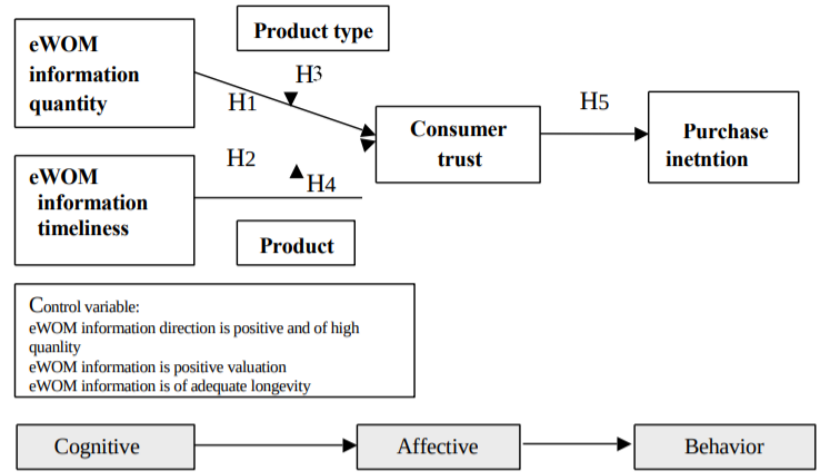

Figure 16. The model of eWOM information, consumer trust and purchase intention by Xiaorong, Bin, Qinghong, Liuli, \& Yu (2011)

\section{Theoretical Framework and Research Methodology}

3.1 Theoretical Framework 
After reviewing the literature model, this research will build on Technology Acceptance Model (TAM) by Davis (1989) with the addition of Perceived Risk as Independent variable, moderating variables, Demography, Social media and Psychological factors along with the COVID-19 factor as a mediating variable as explained in Table 1 and Figure 17 in the below.

Table 1. Variables mapping table

\begin{tabular}{|c|c|c|}
\hline Theoretical Framework Variables & Variable Type & Source \\
\hline Perceived Ease of Use & Independent Variable & $\begin{array}{l}\text { Technology Acceptance Model (TAM) } \\
\text { by Davis (1989). }\end{array}$ \\
\hline Perceived Usefulness & Independent Variable & $\begin{array}{l}\text { Technology Acceptance Model (TAM) } \\
\text { by Davis (1989). }\end{array}$ \\
\hline Perceived Risk & Independent Variable & Nayyar \& Gupta (2011) Model \\
\hline Demography & Moderating Variable & Nayyar \& Gupta (2011) Model \\
\hline Psychological factors & Moderating Variable & Neger \& Uddin (2020) Model \\
\hline eWOM & Moderating Variable & $\begin{array}{l}\text { Rahman, Khan, Abdul Hamid, Latiff, \& } \\
\text { Mahmood (2018) Model }\end{array}$ \\
\hline Categories & Moderating Variable & --- \\
\hline COVID-19 & Mediating Variable & --- \\
\hline
\end{tabular}

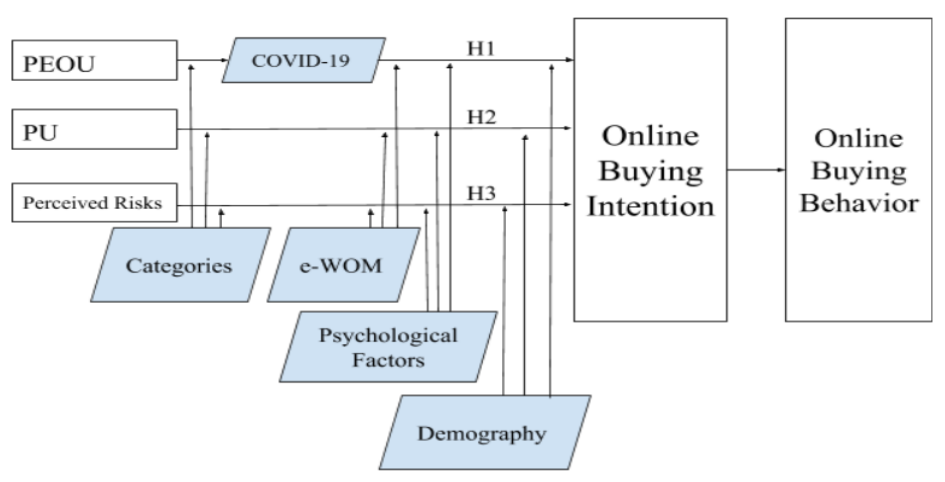

Figure 17. Theoretical framework

- Dependent Variable

Online Buying Intention as a Determinant of Behavior: It's a consumer willingness to select and/or buy a product or service via the internet that leads to the actual action of purchase.

- Independent Variables

I1: Perceived Ease Of Use: "Perceived ease of use on the other hand, indicates how the users perceive the ease of using the technology" (Nayyar \& Gupta, 2011).

I2: Perceived Usefulness: Perceived usefulness is measured through the improvement incurred due to the use of technology in terms of performance or productivity (Nayyar \& Gupta, 2011).

I3: Perceived Risk: "Perceived risk is defined as a functional or psychosocial risk a consumer feels he or she is taking when purchasing a product" (Nayyar \& Gupta, 2011). 


\section{- Moderator Variables}

M1: Psychological Factors: "The psychological factor consists of four key elements: motivation, perception, learning, and attitudes or beliefs" (Neger \& Uddin, 2020).

M2: e-WOM: The informal transfer of information about sold products in the form product reviews and sales over the internet (Sien \& Falahat, 2015).

M3: Demography: As in individual differences in terms of Gender, Age, Monthly income, Location, Occupation (Educational level), Experience with the Internet.

M4: Categories: As in the categories of the ready-made garments that are available for online shopping in Egypt.

- Mediating Variables

COVID-19 Pandemic: With social distancing procedures, it's preferred to order than actually go and buy which makes online purchase more appealing.

3.2 Research Questions

3.2.1 Major Research Questions

MjRQ1: What are the changes in Online Buying Intention as a Determinant of Behavior?

3.2.2 Minor Research Questions

MinRQ1: Does the Perceived Ease of Use affect Online Buying Intention as a Determinant of Behavior?

MinRQ2: Does Perceived Usefulness affect Online Buying Intention as a Determinant of Behavior?

MinRQ3: Do Perceived Risks affect Online Buying Intention as a Determinant of Behavior?

MinRQ4: Do Psychological Factors affect Online Buying Intention as a Determinant of Behavior?

MinRQ5: Does the e-WOM affect Online Buying Intention as a Determinant of Behavior?

MinRQ6: Does the Demography affect Online Buying Intention as a Determinant of Behavior?

MinRQ7: Does the COVID-19 Pandemic affect Online Buying Intention as a Determinant of Behavior?

MinRQ8: Does the Categories affect Online Buying Intention as a Determinant of Behavior?

\subsection{Hypothetical Statements}

$H 1_{0}$ : The Ease Of Use increased consumers towards Online Buying Intention as a determinant of Behavior [Positive Relationship]

$H 1_{a}$ : The Perceived Ease Of Use increased consumers towards Online Buying Intention as a determinant of Behavior [Positive Relationship]

According to Technology Acceptance Model (TAM) by Davis (1989) and Nayyar \& Gupta (2011) Model, Perceived Ease of Use affects the Online Buying Intention positively.

$H 2_{0}$ : The Diversity of the products increases Online Buying Intention as a determinant of Behavior. [Positive Relationship]

$H 2_{a}$ : The Perceived Usefulness of the products increases Online Buying Intention as a determinant of Behavior. [Positive Relationship]

According to Technology Acceptance Model (TAM) by Davis (1989) and Nayyar \& Gupta (2011) Model, Perceived Usefulness affects the Online Buying Intention positively.

$H 3_{0}$ : Security Factors decrease Online Buying Intention as a determinant of Behavior. [Negative Relationship] $H 3_{a}$ : Perceived Risks decrease Online Buying Intention as a determinant of Behavior. [Negative Relationship] According to Nayyar \& Gupta (2011) Model, Perceived Risks affect the Online Buying Intention negatively. $H 4_{0}$ : The FOMO increases Online Buying Intention as a determinant of Behavior. [Positive Relationship] $H 4_{a}$ : The Psychological Factors moderate the relationship between the independent variables and Online Buying Intention as a determinant of Behavior. [Positive Relationship]

According Neger \& Uddin (2020), the Psychological factors were associated with the online shopping behavior during the COVID-19, so it will be added as a moderating variable to be tested in the model.

$H 5_{0}$ : Social Media Influence increases Online Buying Intention as a determinant of Behavior. [Positive Relationship] 
$H 5_{a}$ : e-WOM moderates the relationship between the independent variables and Online Buying Intention as a determinant of Behavior. [Positive Relationship]

According to Rahman, Khan, Abdul Hamid, Latiff, \& Mahmood (2018), e-WOM positively influenced online buying intention. So it will be added as a moderating variable to be tested in the model.

$H 6_{0}$ : Demography has no effect on Online Buying Intention as a determinant of Behavior. $H 6_{a}$ : Demography moderates the relationship between the independent variables and Online Buying Intention as a determinant of Behavior. [Positive Relationship]

According to Nayyar \& Gupta (2011) Model, Demography moderates the relationship with the Online Buying Intention positively.

$H 7_{0}$ : The COVID-19 Pandemic increases Online Buying Intention as a determinant of Behavior. [Positive Relationship]

$H 7_{a}$ : The COVID-19 Pandemic moderates the relationship between the independent variables and Online Buying Intention as a determinant of Behavior. [Positive Relationship]

According Neger \& Uddin (2020) study and stakeholder analysis, it will be added as a mediating variable to be tested in the model as per the increased frequency noticed in the problem definition.

$H 6_{0}$ : Categories have no effect on Online Buying Intention as a determinant of Behavior.

$H 6_{a}$ : Categories moderate the relationship between the independent variables and Online Buying Intention as a determinant of Behavior. [Positive Relationship]

According to the customer interviews, the categories of the ready-made garment was associated with the online buying intention based on the customers' feedback.

\subsection{Methodology}

The stakeholder analysis included Interviews with the customers in order to collect primary data for the research, reflect their real opinions and experiences, evaluate the factors that affect the online shopping intention as determinant of behavior.

\subsubsection{Research Type}

This research follows Quantitative paradigm, for exploratory and descriptive purposes using deductive logic, data was processed in quantitative manner with applied outcome in a cross-sectional time horizon.

\subsection{Data Collection and Analysis}

The interview was conducted using an online survey using Google Forms that was distributed over social media. The questions included were open-ended questions in order to collect and analyze the repondants' answers. The results were then summarized and concluded.

Table 2. Relationship between Questions \& Variables

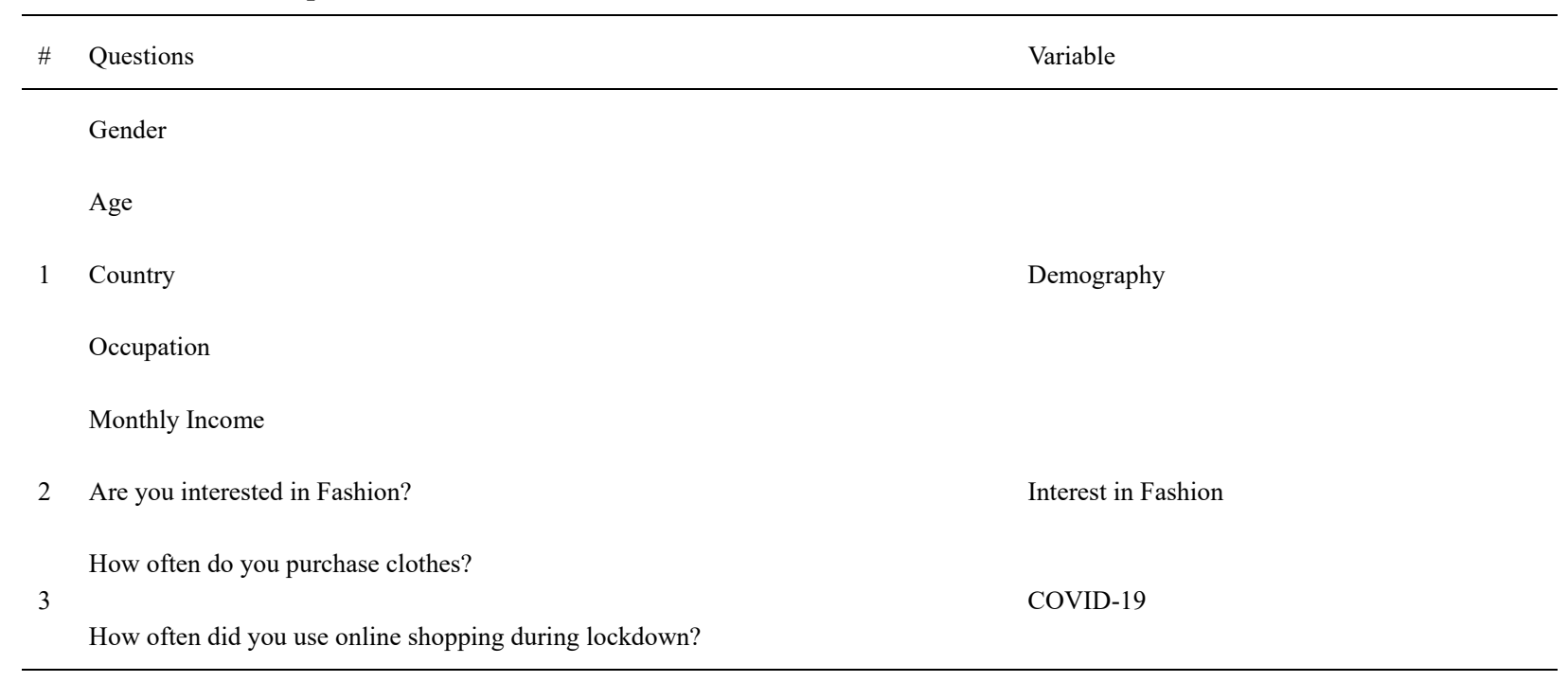


4 From where do you buy your clothes? Mention as many stores as you can.

5

Have you ever purchased clothes online?

6

Mention something you like about shopping for clothes online.

7 Mention something you don't like about shopping for clothes online.

Do you have a social media account?

Do you follow sales/offers for clothes over social media?

Have you ever purchased clothes over social media stores?

9

What do you think about online stores over social media?
Categories for online shopping in Egypt

Customer initial perception or feedback

---

Perceived Ease of Use

Perceived Usefulness

Perceived Risks

Psychological factors

$---$

e-WOM

The above questionnaire was sent to 500 customers and 23 responses were received and the following part will explain every set of questions to measure each variable in the table. According to the above table, every set of questions is matched to a variable from the theoretical framework then the collected data is summarized in the same order as per the below.

1. To summarize the demographic settings of the respondents, they included both genders 17 females and 6 males, females age group is from 26 to 39 years old while males age group is from 31 to 39 years old. Only 17 respondents are living in Egypt while the rest were from the US, UK and Germany. The respondents' feedback who are not living in Egypt were excluded from the following analysis. Regarding the occupation, the majority of the respondents are from either IT or Engineering backgrounds except 3 who are in academic positions. It has been found that 2 respondents' monthly income was between 5,000 LE and 10,000 LE, 5 respondents' monthly income was between 10,000 LE and 20,000 LE while the rest are over 20,000 LE per month.

2. As for the interest in fashion, 2 respondents weren't interested in fashion, 8 respondents weren't sure, 8 respondents confirmed their interest in fashion. However, 16 of them tried purchasing ready-made garments online. Only 2 respondents didn't try to buy online and their interest in fashion wasn't positively or negatively confirmed.

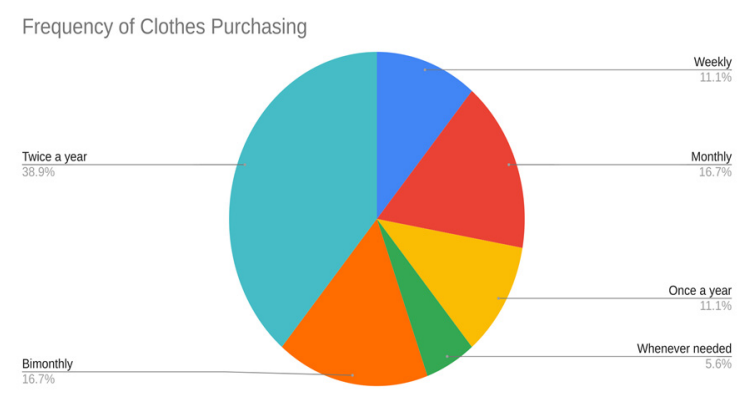

Figure 18. Frequency of clothes purchasing chart 


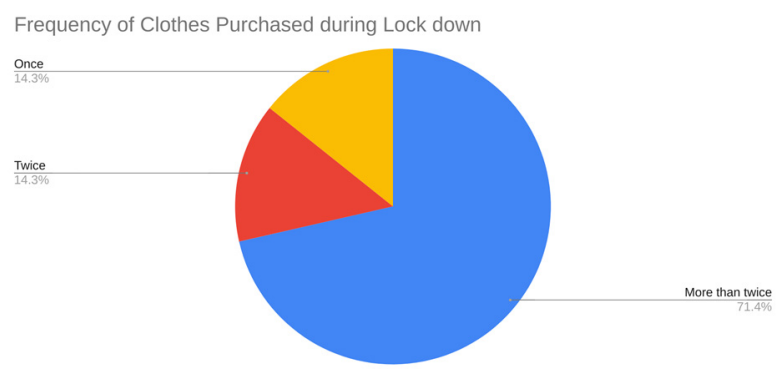

Figure 19. Frequency of clothes purchasing during lockdown chart

As for the impact of the COVID-19 on the frequency of online purchasing and according to figure 18 and 19 , The frequency of buying ready-made garments was different from respondent to another with a majority of $38.9 \%$ saying twice a year which is an indicator of the general frequency regardless of the lockdown. However, the majority of $71.4 \%$ increased their use during the lockdown to more than twice which means an increase of $32.5 \%$ as a result of COVID-19.

As for the categories according to the respondents, ready-made garments brands can be classified into local brands such as Premoda, Shopfufa, Topshop, Carina, Emma, Charmaine. Also international brands such as, Zara, Vero Moda, Oysho, H\&M, Max, American Eagle, Promod, Springfield, Mango, Nike, Gap, Stradivarius, Gant, Pull \& Bear, Defacto, Levis, US polo, J\&J, Columbia, Skechers, Massimo Dutti, LC Waikiki, Mono, Tommy, ecco, Reserved, Adidas, Bershka, Ted Baker, Under Armor, Karen Millen. There's another option to reach international brands that don't have retails in Egypt using Amazon, Yashry, Social media groups that buy from abroad upon request.

Following the initial perception or feedback of the respondents' experience with online purchasing for ready-made garments. 16 feedbacks were received as the below, "Good" and "Nice" was mentioned 3 times while "Very Good" and "Great" eash was mentioned once. Below are the consolidated feedback:

- I love it

- I can't rely on it for my full wardrobe, I need to check the fit and material.

- I had tried it three times, once wasn't satisfied with material and quality, another one didn't realize that sleeves weren't full length, third was satisfied

- Good

- Saves a lot of time/ energy and money(because you can track and trace items till they go on a proper clearance)

- A nice experience

- It's nice

- Very Good, in case you know your correct size

- Best alternative during Covid 19

- Great

- Sometimes value for money

- Easy to access its size charts and well presented. The purchase is just a click of a button away.

- $\quad$ Easy to access

- Nice but not in all stuffs

The previous points show the captured statement/ words that reflects the presence of a positive initial perception/ feedback on their online purchase experiences.

As for the perceived ease of use and perceived usefulness, it was found that the word "easy" was mentioned 7 times which confirms the perceived ease of use of the respondents who tried online purchasing. While the accessibility, time saving, working hours and comparison was correlated with the perceived usefulness of the online purchases. Below are the consolidated feedback: 
- Accessibility to all shops

- Less effort, done from comfort of your home

- Open all the time - faster to check something out

- Saving time

- Easy

- It's easy, you can find online offers that are not in stores, helping getting what you want in the corona virus situation

- Variety and Price

- Discount

- Overseas purchasing

- $\quad$ Price and quality

- Easy browsing and comparing

- Easy to purchase

- Promo Codes and easier

The previous points show the captured statement/ words that reflects the presence of perceived ease of use and perceived usefulness variables.

As for the perceived risk, it can be classified into product related risks such as size, color, design and fabric, payment related risks such as online payment, exposure of personal information, and process related risks such as delivery time, returns. Below are the consolidated feedback:

- Payment through visa

- That I don't try clothes on first, not feeling secure about online visa payment, refund options limitations

- Delivery time-Returns might not be easy and also items could look different on reality

- Sometimes I am worried about the fit. But for some reason i am lucky with it

- Wrong sizes

- I'm not always ordering the perfect size

- In-accurate size chart

- Size and colors sometime not available

- Item online doesn't match delivered one

- Wrong (misleading) fit sizes

- Delivery time

- Ensuring the perfect size

- I slip and buy many things beyond my financial capability. it promotes being shopaholic

- Delivery time

- Size charts sometimes not accurate

The previous points show the captured statement/ words that reflects the presence of perceived risks variable and led to the above categorization of these risks.

As for the psychological factors, one of the most commonly used factors are sales and offers. It was found that $56 \%$ of the respondents follow sales and offers online according to figure 20. This can indicate that the relationship between the psychological factors and the online buying intention. 


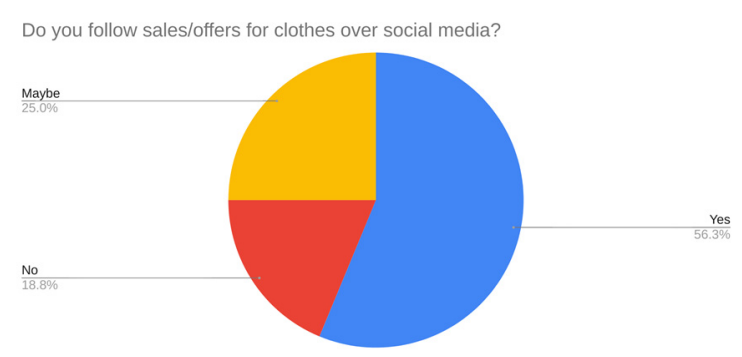

Figure 20. Percentage of customers following offers/sales online over social media

As for the e-WOM, the majority of the respondents' feedback was positive according to their experience in terms of the communication with the store owner, reviews, and sales notifications. While others expressed similar points to the perceived risks in point \#7. The words "Nice", "Good" and "Perfect" were mentioned 3 times. Below are the collected feedbacks:

- Nice

- It allows access to other customers feedback

- Experience is very variable as per store personnel

- Sometimes they are brilliant and some others they suck

- They are good

- You get notified about new collection of sale

- Untrusted and risky

- I think good

- Needs regulations to assure customer rights

- Usually not the best prices, overpriced especially in Egypt, many fake items, not trusted

- Didn't try

- Perfect

- Nice but not in all stuffs

The previous points show the captured statement/ words that reflects the presence of the e-WOM variable.

\section{Conclusion, Recommendation and Future Work}

\subsection{Conclusion}

With thorough consideration of the problem definition and literature review, it can be concluded that the changes in Online Buying Intention as determinant of Behavior during the COVID-19 pandemic in Ready-made Garments Industry in Egypt can be measured by a set of variables, Perceived Ease of Use, Perceived Usefulness, Perceived Risks, Demography, eWOM, Psychological Factors, Categories and COVID-19. 


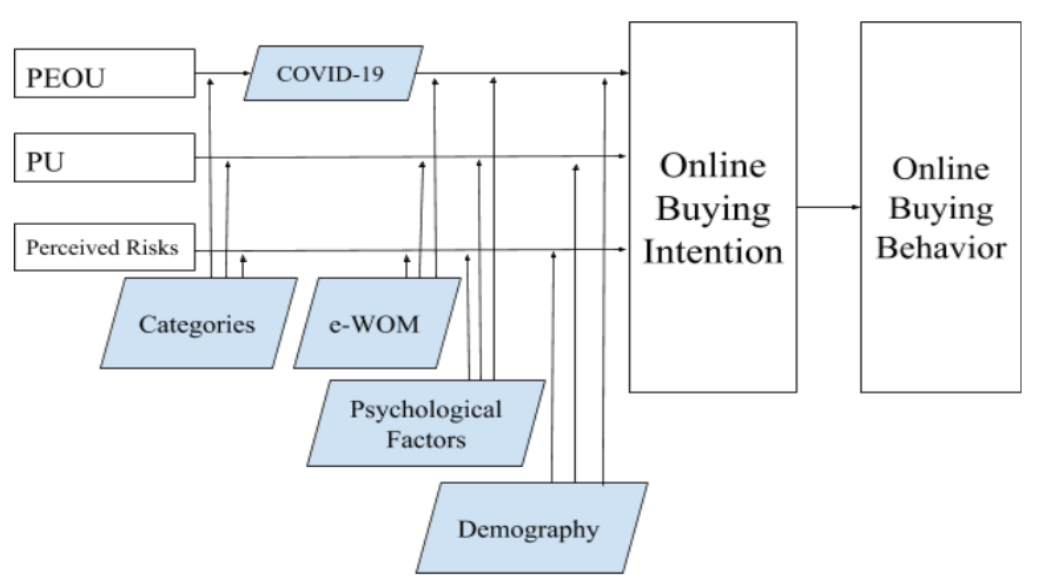

Figure 21. The proposed model

The above model was concluded through the collection of the primary data through stakeholder analysis via customer interviews and secondary data from previous models and theories. The collected primary data led to the following findings.

The first set of the questions is used to create the selection criteria of the respondents' demographic settings and exclude respondents who are not living in Egypt as the respondents were from Egypt, US, UK and Germany. The selected respondents' demographic settings, both genders were included who are living in Egypt with college education aged from 26-39 years old in the middle and high social class based on monthly income range from 5,000 EGP to over 20,000 EGP. Some respondents showed interest in fashion while others didn't, this showed that interest in fashion is not a factor in buying clothes as all of them confirmed that they tried buying ready-made garments.

One major finding is that the frequency of clothes buying has increased by $32.5 \%$ as a result of the COVID-19 pandemic. It was also found that Ready-made garments brands can be classified into local brands and international brands, there's an import option upon request. Also, the number of local brands is below the quarter of international brands, which reflects an insight on the market and customer preference.

Regarding the experience of online buying intention as a determinant of behavior, the respondents described it as a nice experience overall as it was easy, in terms of finding the right size and color, saving time and effort in retail stores, some actually described it convenient as "One button click away". They also listed accessibility, ease of use, time saver, having a variety of alternatives and discounts as positive outcomes of their experiences, while some showed concerns about the product, process and payment methods which complies with the proposed model perceived ease of use, perceived usefulness and perceived risks.

As for the relationship between the online buying intention and psychological factors, it was addressed from sales/ offers perceptive and it was positive as $56 \%$ of the respondents follow sales and offers online. As for the e-WOM, the relationship was positively concluded and supported by the respondents' majority of positive feedback.

\subsection{Recommendation}

According to the findings of this research, the below recommendation can be concluded into 2 major categories:

$>$ To build on the positive relationships:

- The introduction of new local brands ready-made garments is an open area for investment as the market share is below $25 \%$.

- The use of new technologies for enhancing the online buying experience in terms of easy features in order to increase the online buying intention hence induce behavior.

- The use of new technologies for enhancing the online buying experience in terms of useful features in order to increase the online buying intention hence induce behavior.

- $\quad$ Applying price discrimination to attract different levels of social classes to purchase online.

- $\quad$ Using tools of e-WOM and psychology to induce online buying intention. 
> To avoid and control risks and negative risks:

- The use of new technologies for safe and secure payment transactions.

- $\quad$ Applying regulations in order to assure customers' rights in terms of returns and fraud.

4.3 Future Work

> Using the currently adapted model (TAM) by Davis (1989):

- Include variety of respondents with different demographic setting such education, social class and country

- Include statistics with a breakdown by government inside in Egypt

- $\quad$ Include a Quantitative analysis for the collected data

$>$ Using different models:

- Use another model for intention and compare results such as Theory of planned behavior (TPB) by Ajzen (1991).

- Using a comprehensive model to measure every aspect of online buying behavior such as Comprehensive model by Şen (2019).

\section{References}

Abdelhafz, A. S., Mohammed, Z., Ibrahim, M. E., Ziady, H. H., Alorabi, M., Ayyad, M., \& Sultan, E. A. (2020). Knowledge, Perceptions, and Attitude of Egyptians Towards the Novel Coronavirus Disease (COVID-19). Journal of Community Health. https://doi.org/10.1007/s10900-020-00827-7

Ahmad, A. R., Hoda, N., AlHazmi, B., Melibari, A., \& Althubiani, M. (2014). Determinants of Online Buying Behavior of Social Media Users in Saudi Arabia: An Exploratory Study. SSRN Electronic Journal. https://doi.org/10.2139/ssrn.2519254

Ajzen, I. (1991). Organizational Behavior and Human Decision Processes (50th ed., pp. 179-211). Academic Press. Inc. https://doi.org/10.1016/0749-5978(91)90020-T

Archived: WHO Timeline - COVID-19. (2020). WHO | World Health Organization. https://www.who.int/news-room/detail/27-04-2020-who-timeline---covid-19

Aref, M. M., \& Okasha, A. E. (2020). Evaluating the online shopping behavior among Egyptian college-educated community. Review of Economics and Political Science. https://doi.org/10.1108/REPS-10-2018-0013

Balau, M. (2018). Exploring the Link between Intention and Behavior in Consumer Research. Research Gate.

Bhattacherjee, A. (2001). Understanding Information Systems Continuance: An Expectation-Confirmation Model. MIS Quarterly, 3, 351. https://doi.org/10.2307/3250921

Chiu, C. M., Hsu, M.-H., Lai, H., \& Chang, C.-M. (2010). Exploring Online Repeat Purchase Intentions: The Role of Habit . PACIS.

Davis, F. D. (1989). Perceived Usefulness, Perceived Ease of Use, and User Acceptance of Information Technology. MIS Quarterly, 3, 319. https://doi.org/10.2307/249008

Davis, F. D. (1993). User acceptance of information technology: system characteristics, user perceptions and behavioral impacts. International Journal of Man-Machine Studies, 3, 475-487. https://doi.org/10.1006/imms.1993.1022

Davis, F. D., Bagozzi, R. P., \& Warshaw, P. R. (1989). User acceptance of computer technology: a comparison of two theoretical models. Management Science. https://doi.org/10.1287/mnsc.35.8.982

El Ansary, O., \& Roushdy, A. S. (2013). Factors Affecting Egyptian Consumers' Intentions for Accepting Online Shopping. The Journal of American Academy of Business, Cambridge.

ElSafty, A. (2018). Business Research Methods. Egypt: Lecture Notes, Lecture One.

Elsafty, A. (2018). Lecture 2: Scientific Business Research Problem Definition [PowerPoint slides]. Retrieved from Maastricht School of Management, MBA Degree.

Elsafty, A. (2018). Lecture 2: Scientific Business Research Problem Definition [Lecture]. Retrieved from Maastricht School of Management, MBA Degree.

Elsafty, A. (2020). DrAshrafElsafty Channel. Retrieved from Youtube: https://www.youtube.com/watch?v=y-jDT2iOOhU\&list=PLKSWZdnzp8p3uFLLh2N8_d0W7ZmJDLMjW 
\&index $=42 \& \mathrm{t}=628 \mathrm{~s}$

Elsafty, A., \& AlNawaly, A. (2020). Role of Co-Working Spaces' Services in Entrepreneurs Growth in Upper Egypt, The Case of Step Co-Working Space. Business and Management Studies, 6(2). https://doi.org/10.11114/bms.v6i2.4899

Elsafty, A., \& Elzeftawy, A. (2021). The New Era of Digital Transformation and COVID-19 Effect on The Employment in Mobile Operators in Egypt. Business and Management Studies, 7(1), 74-99. doi:http://dx.doi.org/10.11114/bms.v7i1.5145

Elsafty, A., \& Ragheb, M. (2020). Role of Human Resource Management towards Employees Retention during Covid-19 Pandemic. Business and Management Studies, 6(2). https://doi.org/10.11114/bms.v6i2.4899

Elsafty, A., \& Tahon, A. (2020). Exploring Impact of Corporate Social Responsibility on Organizational Performance, the Case of Turkish Islamic Banks. Business and Management Studies, 7(1), 1-21. doi:http://dx.doi.org/10.11114/bms.v7i1.5087

Elsafty, A., Abadir, D., \& Shaarawy, A. (2020). How Does the Entrepreneurs' Financial, Human, Social and Psychological Capitals Impact Entrepreneur's Success?. Business and Management Studies, 6(3), 55-71. https://doi.org/10.11114/bms.v6i3.4980

Elsafty, A., Elbouseery, I., \& Shaarawy, A. (2020). Factors Affecting the Behavioral Intention to Use Standalone Electronic Personal Health Record Applications by Adults in Egypt. Business and Management Studies, 6(4), 14-36. https://doi.org/10.11114/bms.v6i4.5066

Elsafty, A., Elsayed, H., \& Shaaban, I. (2020), A Business Analysis Perspective for Engineering Education in Egypt. Journal of Education and Training Studies, 8(5). https://doi.org/10.11114/jets.v8i5.4721

Elsafty, A., Elsayed, H., \& Shaaban, I. (2020). Educating Engineering Students in Egypt: Recommendations for Improvement. International Journal of Higher Education. https://doi.org/10.5430/ijhe.v9n3p1

Elsafty, A., Elsayed, H., \& Shaaban, I. (2020). Journal of Education and Training Studies, 8(8). https://doi.org/10.11114/jets.v8i8.4901

El-Zarka, S. (2010). Designing A Competency Framework for Logistics Executives: The Case Of The Ready-Made Garments Manufacturers In Egypt - University of Huddersfield Repository. In Welcome to the University of Huddersfield Repository - University of Huddersfield Repository. http://eprints.hud.ac.uk/id/eprint/9827/

Fayad, R., \& Paper, D. (2015). The Technology Acceptance Model E-Commerce Extension: A Conceptual Framework. Procedia Economics and Finance, 1000-1006. https://doi.org/10.1016/s2212-5671(15)00922-3

Fishbein, M., \& Ajzen, I. (1975). Belief, Attitude, Intention, and Behavior. Addison-Wesley.

Hasab, A. A., El-Ghitany, E. M., \& Ahmed, N. N. (2020). Situational Analysis and Epidemic Modeling of COVID-19 in Egypt. Journal of High Institute of Public Health. https://doi.org/10.21608/jhiph.2020.87076

Humphrey, D. B., Pulley, L. B., \& Vesala, J. M. (1996). Cash, Paper, and Electronic Payments: A Cross-Country Analysis. Journal of Money, Credit and Banking, 4, 914. https://doi.org/10.2307/2077928

Kemp, S. (2020, February 17). Digital 2020: Egypt - DataReportal - Global Digital Insights. DataReportal Global Digital Insights; DataReportal $\quad-\quad$ Global Digital Insights. https://datareportal.com/reports/digital-2020-egypt

Kim, D. J. (2012). An investigation of the effect of online consumer trust on expectation, satisfaction, and post-expectation. Information Systems and E-Business Management. https://doi.org/10.1007/s10257-010-0136-2

Kotler, P., \& Armstrong, G. M. (2012). Principles of Marketing (14th ed., p. 613). Pearson Prentice Hall.

Kumar, V., \& Dange, U. (2012). A Study of Factors Affecting Online Buying Behavior: A Conceptual Model. SSRN Electronic Journal. https://doi.org/10.2139/ssrn.2285350

Mishra, S. B., \& Singh, S. R. (2020). Covid-19: Post Lockdown Challenges and Opportunities for Readymade Garments Sector in Indore City.

Nayyar, R., \& Gupta, S. L. (2011). Determinants of Internet Buying Behavior in India. Asian Journal of Business Research. https://doi.org/10.14707/ajbr.110011

Neger, M., \& Uddin, B. (2020). Factors Affecting Consumers' Internet Shopping Behavior During the COVID-19 
Pandemic: Evidence from Bangladesh. Chinese Business Review. https://doi.org/10.17265/1537-1506/2020.03.003

Pavlou, P. A., \& Fygenson, M. (2006). Understanding and Predicting Electronic Commerce Adoption: An Extension of the Theory of Planned Behavior. MIS Quarterly, 1, 115. https://doi.org/10.2307/25148720

Rahman, M. A., Khan, S. A., Abdul Hamid, A. B., Latiff, A. S. A., \& Mahmood, R. (2018). Impact of Electronic Word of Mouth (e-WOM) on Brand Image and Online Purchase Intention: The Perspective of Bangladesh. SSRN Electronic Journal. https://doi.org/10.2139/ssrn.3490628

Rogers, E. M. (1995). Diffusion of Innovations: Modifications of a Model for Telecommunications. Stoetzer MW., Mahler A. (Eds) Die Diffusion von Innovationen in Der Telekommunikation. Schriftenreihe Des Wissenschaftichen Instituts Für

Kommunikationsdienste. https://doi.org/https://doi.org/10.1007/978-3-642-79868-9_2

Şen, Ö. (2019). Research of Online Purchasing Behavior with, Theory of Planned Behavior, Technology Acceptance Model, Diffusion of Innovation Theory, Consumer Habits And Trust Factors. Social Sciences Studies Journal. https://doi.org/10.26449/sssj.1698

Sien, L. Y., \& Falahat, M. (2015). Conceptualising Consumers' Purchase Intention towards Online Group Buying. Global Journal of Business and Social Science Review.

Teodoro, A., \& Rodriguez, L. (2020, May 29). Textile and garment supply chains in times of COVID-19: challenges for developing countries | UNCTAD. Home | UNCTAD. Retrieved from https://unctad.org/news/textile-and-garment-supply-chains-times-covid-19-challenges-developing-countries

Vazquez, D., \& Xu, X. (2008). Investigating linkages between online purchase behaviour variables. International Journal of Retail \& Distribution Management. https://doi.org/10.1108/09590550910954900

Xiaorong, F., Bin, Z., Qinghong, X., Liuli, X., \& Yu, C. (2011). Impact of Quantity and Timeliness of EWOM Information on Consumer's Online Purchase Intention under C2C Environment. Asian Journal of Business Research.

\section{Appendix A: Questionnaire}

\begin{tabular}{|c|c|}
\hline Question & Response \\
\hline Gender: & $\begin{array}{l}\text { Female } \\
\text { Male }\end{array}$ \\
\hline Age: & Short answer text \\
\hline Country: & Short answer text \\
\hline Occupation: & Short answer text \\
\hline Monthly Income: & $\begin{array}{l}\text { Less than } 3000 \mathrm{LE} \\
\text { Between 3,000 LE and 5,000 LE } \\
\text { Between 5,000 LE and 10,000 LE } \\
\text { Between 10,000 LE and 20,000 LE } \\
\text { More than 20,000 }\end{array}$ \\
\hline Are you interested in Fashion? & $\begin{array}{l}\text { Yes } \\
\text { No } \\
\text { Maybe }\end{array}$ \\
\hline How often do you purchase clothes? & $\begin{array}{l}\text { Weekly } \\
\text { Monthly } \\
\text { Bimonthly } \\
\text { Twice a year } \\
\text { Once a year } \\
\text { Other }\end{array}$ \\
\hline
\end{tabular}




\begin{tabular}{ll}
\hline How often did you use online shopping during lockdown? & Once \\
& Twice \\
From where do you buy your clothes? Mention as many stores as you can. & Long answer text \\
What do you think about online shopping? & Long answer text \\
Have you ever purchased clothes online? & Yes \\
Mention something you like about shopping for clothes online. & No \\
Mention something you don't like about shopping for clothes online. & Long answer text \\
Do you have a social media account? & Long answer text \\
& Yes \\
Do you follow sales/offers for clothes over social media? & No \\
& Yes \\
Have you ever purchased clothes over social media stores? & oNo \\
& Maybe \\
\hline
\end{tabular}

\section{Copyrights}

Copyright for this article is retained by the author(s), with first publication rights granted to the journal.

This is an open-access article distributed under the terms and conditions of the Creative Commons Attribution license (http://creativecommons.org/licenses/by/4.0/). 